\title{
Yield attributes and nutrient uptake of organic safflower (Carthamus tinctorius L.) in drylands of Maharashtra
}

\author{
S.V. KHADTARE*, S.K. SHINDE AND V.M. TORADMAL \\ AICRP on Safflower, Zonal Agricultural Research Station (M.P.K.V.), SOLAPUR (M.S.) INDIA \\ (Email : khadtareagronomy@gmail.com)
}

\begin{abstract}
A field experiment on 'organic farming' in safflower was conducted at Dry Farming Research Station (DFRS), Solapur for five years (2009-10 to 2013-14) with the objective to explore the possibilities of substituting chemical inputs through organic source and to evaluate its effect on nutrient uptake. Well decomposed farm yard manure, vermicompost, neem seed cake, Azotobacter, Tricoderma and neem seed kernel extract were used as organic inputs. While, urea, SSP, dimethoate and arbendezim were used as synthetic sources of inputs. Significantly higher seed yield $\left(1189 \mathrm{~kg} \mathrm{ha}^{-1}\right)$ of safflower was recorded under RDF (50:25:0 NPK kg/ha + chemical control). Treatment with application of FYM @ 5ton/ha + BF+ biopesticide (Neem cake @ 200kg/ ha, Trichoderma seed treatment @ $5 \mathrm{~g} / \mathrm{kg}$ seed + spray of NSKE 5\%) and treatment FYM alone @ 6.5 ton/ha were at par with RDF (50:25:0) NPK kg/ha + chemical control. Numerically higher values of test weight $(5.87 \mathrm{~g})$ were recorded under (FYM @ 2.5 ton/ha + biofertilizer) and $\mathrm{T}_{8}(\mathrm{FYM}$ (equal to $\left.50 \mathrm{~kg} \mathrm{~N})=6.5 \mathrm{ton} / \mathrm{ha}\right)$. Higher volume weight $\left(722 \mathrm{~g} \mathrm{lit}^{-1}\right)$ was recorded under the treatment $\mathrm{T}_{3}$. Significantly higher uptake of nitrogen was recorded under $\mathrm{T}_{9}$ i.e. $\operatorname{RDF}(50: 25: 0) \mathrm{NPK} \mathrm{kg} / \mathrm{ha}+$ chemical control and it was at par with $\mathrm{T}_{3}$ i.e FYM @ 5ton/ha $+\mathrm{BF}+$ biopesticide in respect of $\mathrm{P}_{2} \mathrm{O}_{5}$ and $\mathrm{K}_{2} \mathrm{O}$.
\end{abstract}

Key Words : Biofertilizer, LAI, Safflower, NSKE, TDM, Uptake

View Point Article : Khadtare, S.V., Shinde, S.K. and Toradmal, V.M. (2016). Yield attributes and nutrient uptake of organic safflower (Carthamus tinctorius L.) in drylands of Maharashtra. Internat. J. agric. Sci., 12 (2) : 314-318, DOI:10.15740/HAS/IJAS/12.2/314-318.

Article History : Received : 01.03.2016; Revised : 20.03.2016; Accepted : 17.05.2016 